\title{
THE EFFECT OF PROFESSIONALISM, OBJECTIVITY, ACCOUNTABILITY, KNOWLEDGE OF THE ACCURACY OF GIVING AUDIT OPINION AND AUDITOR EXPERIENCE AS MODERATING VARIABLES
}

\author{
Hari Setiawan'), Aris Sanulika ${ }^{2)}$ \\ Universitas Pamulang \\ dosen01254@unpam.ac.id
}

\begin{abstract}
The auditor as a party trusted by the public, the auditor will examine the financial statements and then issue a statement. Research wants to know the effect professionalism, objectivity, accountability, knowledge on the accuracy of the provision of audit opinions and auditor experience as a moderating variable on the influence of audit expertise on the accuracy of giving opinions by the auditor.The data used in this study are quantitative data and statistical data processing used is moderated regression analysis. The source of data in this study is primary data. The population in this study were auditors who worked at KAP located in South Tangerang. The sampling technique in this study used the probability sampling method - Simple Random Sampling, with 58 respondents. The results of this study indicate that professionalism, objectivity, accountability, knowledge do not affect the accuracy of providing audit opinions either partially or simultaneously.. The auditor's experience can moderate the variables of professionalism, objectivity, accountability, knowledge of the accuracy of the giving of audit opinions
\end{abstract}

Keywords: Professionalism; Objectivity; Accountability; Knowledge of the Accuracy of Providing Auditor's Opinion; Auditor's Experience

\section{INTRODUCTION}

The auditor as a party trusted by the public, the auditor will examine the financial statements and then issue a statement. The great trust of the users of financial statements is what ultimately requires the auditor to pay attention to the quality of the resulting audit.

Accountability in this study according to M. Taufik (2011), uses three indicators which include: Motivation, devotion to the profession and social obligations. But in this study will use 2 indicators, namely motivation and social obligations. While the indicators of service to the profession will be explained to professionalism.

Objectivity affects the quality of the auditor's work. Article 1 paragraph 2 of the Indonesian Accountant Code of Ethics states that each member must maintain integrity and objectivity in carrying out their duties.
By maintaining integrity, he will act honestly, decisively, and without pretension.

This research is important to be reviewed to deepen the influence of professionalism, objectivity, accountability, knowledge of the accuracy of providing audit opinion and auditor experience as a moderating variable.

\section{LITERATURE REVIEW}

\subsection{Professionalism}

As professionals, auditors have an obligation to fulfill specific rules of behavior that describe an attitude or things that are ideal. This obligation is in the form of fundamental responsibilities for the profession to strengthen the services offered.

As professionals, public accountants acknowledge their responsibilities to the 
community, to clients, and to fellow professionals, including to behave respectfully, even though this is a personal sacrifice.

H1: There is an influence between the professionalism of auditors on the accuracy of giving partial audit opinions.

\subsection{Objectivity}

Objectivity as the freedom of a person from the influence of subjective views of other interested parties. The general standard in IAPI Audit Standards states that with the principle of auditor objectivity, the better the quality of the results of the examination. With the importance of giving an audit opinion, an auditor clearly has an interest in the published audit report.

H2 : There is an influence between the objectivity of auditors on the accuracy of giving partial audit opinions.

\subsection{Accountability}

Accountability held by the auditor can improve the cognitive process of the auditor in making decisions. An auditor really needs to have high accountability to maintain and provide confidence in his sense of responsibility so that clients feel comfortable. The higher an auditor has accountability, the more mature he is to carry out his duties, one of which is ripe in providing audit opinions.

H3 : There is an influence between the auditor's accountability on the accuracy of giving partial audit opinion.

\subsection{Knowledge}

Highly educated auditors will have a broader view of things. Auditors will increasingly have a lot of knowledge about the field they are in, so that they can find out various issues in more depth.

H4: There is an influence between auditor's knowledge on the accuracy of giving partial audit opinion.

\subsection{Auditor's Experience}

Audit experience is the auditor's experience in auditing financial statements in terms of both the length of time and the number of assignments that have been handled.
H5: The auditor's experience is able to moderate the influence of professionalism, objectivity, accountability, knowledge on the accuracy of the giving of audit opinion

\subsection{Accuracy in Giving Audit Opinion}

Accuracy is the similarity or closeness of a measurement result to the actual numbers or data (true value / correct result).

\subsection{Granting Audit Opinion}

At the end of the examination, in a general audit, the KAP will provide an accountant's report consisting of an opinion sheet, which is the responsibility of the public accountant, where the public accountant gives his opinion on the reasonableness of the financial statements prepared by management and is the responsibility of management.

In carrying out its responsibilities as a professional auditor, each auditor must have an attitude of Objectivity, Accountability, knowledge and experience long enough to be able to carry out all audit procedures in accordance with predetermined standards in order to produce quality audit reports. First, the professionalism of a professional in carrying out a profession will usually have a high motivation. Second, objectivity, because objectivity is a quality that gives value to the services provided by its auditor. Third, Accountability, because the quality of the work of the auditor can be influenced by the sense of accountability (accountability) that the auditor has in completing the audit work. Accountability is a social psychological impetus that a person has to fulfill obligations that will be accountable to their environment. Fourth, knowledge, knowledge is the skill of an expert in which the expert is defined as a person who has a certain level of skills gained from training and experience and therefore knowledge is needed in providing audit opinion. Fifth, the Auditor's Experience, the longer an auditor is in charge, the more financial statement audit tasks that have been performed and the more types of companies that have been handled, the practice of terminating premature audit procedures can be avoided. 
H6 : There is an influence between professionalism, objectivity, accountability, knowledge on the accuracy of giving simultaneous audit opinions.

\section{RESEARCH METHOD}

The research design used in this study is a causal design where the causal design is useful for analyzing the relationships between a variable with other variables or how a variable affects other variables. Causal design examines the "causation" relationship is a causal relationship, so there are independent variables (influencing variables) and dependent variables (influenced) and for this test using multiple linear regression with Auditor analysis unit individually.

\subsection{Data Collection Techniques}

The source of data in this study is primary data collection data through field research by distributing questionnaires to respondents.

\subsection{Sample Collection Techniques}

The sampling technique in this study uses a questionnaire with a probability sampling method - Simple Random Sampling, which is a simple random sampling method that provides equal and unlimited opportunities for each member of the population to be selected as a sample.

\subsection{Data Analysis Techniques}

The method of data analysis uses descriptive statistical analysis of data quality tests, classic assumption tests and Moderated Regression Analysis.

\section{RESULTS AND DISCUSSION}

\subsection{Descriptive Statistics Test Results}

Variables used in this study which include professionalism, objectivity, accountability, knowledge, accuracy of opinion giving, and experience will be tested statistically descriptive as shown in table 4.1

Tabel 4.1

\begin{tabular}{|c|c|c|c|c|c|}
\hline \multicolumn{6}{|c|}{ Descriptive Statistics } \\
\hline & $\mathrm{N}$ & Min & $\operatorname{Max}$ & Mean & Std. \\
\hline Profesionalism & 58 & 26 & 35 & 30,7069 & 2,25566 \\
\hline Objektifitas & 58 & 25 & 40 & 33,6379 & 3,08760 \\
\hline Akuntabilitas & 58 & 23 & 33 & 29,5517 & 2,57636 \\
\hline Pengetahuan, & 58 & 26 & 39 & 33,6724 & 2,99934 \\
\hline $\begin{array}{l}\text { Ketepatan_Pem } \\
\text { berian_Opini }\end{array}$ & 58 & 12 & 19 & 15,9655 & 1,72663 \\
\hline Pengalaman & 58 & 13 & 20 & 16,2414 & 1,63632 \\
\hline Valid & 58 & & & & \\
\hline
\end{tabular}

Source : Self Process Data-SPSS ver. 22

Based on the tabulated data summarized as presented in the table above, it can be seen that the professionalism variable, the minimum answer of respondents is 26 and the maximum is 35 , with an average total answer of 30.67. On the objectivity variable the minimum respondent's answers are 25 and the maximum is 40 , with an average total answer of 33.63. In the accountability variable the minimum respondent's answer is 23 and the maximum is 33 , with an average total answer of 29.55. In the knowledge variable the minimum respondent's answers are 26 and the maximum is 39 , with an average total answer of 33.67. In variables, the accuracy of giving minimum opinions of respondents' answers is 12 and the maximum is 19 with an average total of 15.96 answers. In the Experience variable the minimum respondent's answers were 13 and the maximum was 20 , with an average total answer of 16.24 .

\subsection{Coefficient of determination $\left(\mathrm{R}^{2}\right)$}

Tabel 4.2

Determination Coefficient Test Results

Model Summary ${ }^{b}$ 


\begin{tabular}{|c|c|c|c|c|}
\hline \multirow{3}{*}{$\begin{array}{l}\text { Mo } \\
\text { del }\end{array}$} & \multicolumn{4}{|c|}{ R Adjuste } \\
\hline & & Squar & $\mathrm{d} R$ & Std. Error of \\
\hline & $\mathrm{R}$ & $\mathrm{e}$ & Square & the Estimate \\
\hline 1 &, $323^{a}$ & , 104 & ,037 & 1,69475 \\
\hline a. & $\begin{array}{l}\text { Predict } \\
\text { objecti } \\
\text { knowle }\end{array}$ & $\begin{array}{l}\text { rs: (Cor } \\
\text { ty, acc } \\
\text { ge }\end{array}$ & $\begin{array}{l}\text { stant), } \\
\text { untabilit }\end{array}$ & $\begin{array}{l}\text { ofessionalism, } \\
\text { and }\end{array}$ \\
\hline b. & $\begin{array}{l}\text { Depen } \\
\text { Acurac }\end{array}$ & $\begin{array}{l}\text { ent Var } \\
\text { Giving }\end{array}$ & $\begin{array}{l}\text { ble: } \\
\text { Opinion }\end{array}$ & \\
\hline
\end{tabular}

Table 4.2 shows the Adjusted R Square value of 0.104 or $10.4 \%$, this shows that the accuracy of the audit opinion variable that can be explained by the variables of professionalism, objectivity, accountability and knowledge is $10.4 \%$, while the rest is 0.896 or $89.6 \%$ is explained by other factors not included in this research model, such as: Independence, Audit Situation, Audit Ethics and others.

\subsection{Statistical Test $F$}

Tabel 4.3

Statistical Test Results F

ANOVA $^{\mathrm{a}}$

\begin{tabular}{|c|c|c|c|c|c|c|}
\hline & Model & $\begin{array}{l}\text { Sum of } \\
\text { Squares }\end{array}$ & Df & $\begin{array}{l}\text { Mean } \\
\text { Square }\end{array}$ & $\mathrm{F}$ & Sig. \\
\hline \multirow{3}{*}{1} & Regression & 17,705 & 4 & 4,426 & \multirow[t]{3}{*}{1,541} & \multirow[t]{3}{*}{$204^{b}$} \\
\hline & Residual & 152,23 & 53 & 2,872 & & \\
\hline & Total & 169,93 & 57 & & & \\
\hline
\end{tabular}

a. Predictors: (Constant), professionalism, objectivity, accountability and knowledge

b. Dependent Variable: Acuracy_Giving_Opinion

The table shows that the accuracy of giving opinion variables influence in professionalism, objectivity, accountability, knowledge. The table from the $\mathrm{F}$ test obtained the calculated $\mathrm{F}$ value of 1.541 with a significance level of 0.204 .
4.4 Statistical Test T

Tabel 4.4

Statistical Test Results t

\begin{tabular}{|c|r|r|r|r|r|}
\hline \multirow{2}{*}{ Model } & \multicolumn{2}{|c|}{$\begin{array}{c}\text { Unstandardized } \\
\text { Coefficients }\end{array}$} & $\begin{array}{c}\text { Standardized } \\
\text { Coefficients }\end{array}$ & \multirow{2}{*}{$\mathrm{t}$} & \multirow{2}{*}{ Sig. } \\
\cline { 2 - 5 } & B & $\begin{array}{c}\text { Std. } \\
\text { Error }\end{array}$ & Beta & & \\
\hline \multirow{2}{*}{ (Constant) } & 22,071 & 3,502 & & 6,302 & 0 \\
Profesionalism & $-0,063$ & 0,134 & $-0,082$ & $-0,466$ & 0,643 \\
Objektifity & $-0,108$ & 0,131 & $-0,194$ & $-0,825$ & 0,413 \\
Acountability & 0,168 & 0,162 & 0,251 & 1,042 & 0,302 \\
Knowledge & $-0,164$ & 0,156 & $-0,284$ & $-1,049$ & 0,299 \\
\hline
\end{tabular}

a. Predictors: (Constant), professionalism, objectivity, accountability and knowledge

b. Dependent Variable: Acuracy_Giving_Opinion

4.5 Moderated Regression Analysis Results

Tabel 4.5

Moderated Regression Analysis Results

Coefficients $^{\mathrm{a}}$

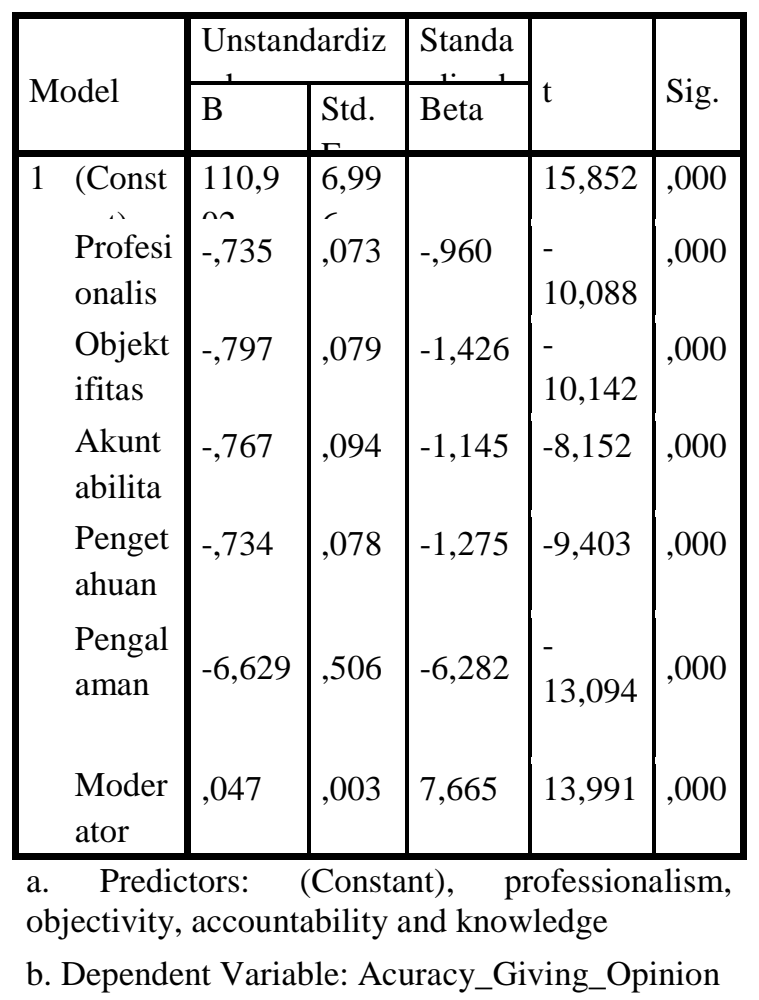




$$
\begin{aligned}
& \mathrm{Y}=22,071+(-0,063) \times 1+(-0,108) \times 2+(0,168) \times 3+(- \\
& 0,164) \times 4 \\
& \mathrm{Y}=110,902+(-0,735) \mathrm{x}_{1} \\
& \mathrm{Y}=110,902+(-0,735) \times 1+(-0,797) \times 2+(-0,767) \times 3+ \\
& \quad(-0,734) \times 4+(6,629) \times 5+0,047 \times 1 \mathrm{X} 2 \mathrm{X} 3 \mathrm{X} 4 \mathrm{X} 5
\end{aligned}
$$

\subsection{Discussion}

Discussion of Hypotheses: The effect of auditor professionalism on the accuracy of giving audit opinions

The professionalism variable $\mathrm{T}$ value of 0.466 with a significance level of 0.643 or greater than the probability value ( $\mathrm{p}$-value) of 0.05 , which means $\mathrm{H} 1$ is rejected.

This is because Professionalism apparently does not serve as a benchmark in the accuracy of providing audit opinions. Because the auditor works in the auditing process based on SPAP, so if the auditor works according to the existing SPAP, it will produce accuracy in giving audit opinion.

Discussion of Hypotheses: Effect of auditor objectivity on the accuracy of giving partial audit opinions

The objectivity variable $T$ value is -0.825 with a significance level of 0.413 or greater than the probability value (p-value) of 0.05 . This means rejecting $\mathrm{H} 2$.

This is because there are still many auditors who cannot accept that there are no easy solutions, and realize that some findings can be subjective, objectivity is the freedom of mental attitude that must be maintained by the auditor in conducting an audit, and the auditor must not let his audit considerations be influenced by other people. Each auditor must maintain objectivity and be free from conflicts of interest in fulfilling his obligations (Principles of Professional Ethics of the Indonesian Institute of Accountants, 1998).

The results of this study support Aprianti, D (2010), Bustami, A (2013) and Fauziyah (2013) research.

Hypothesis Discussion: The effect of auditor accountability on the accuracy of giving partial audit opinions
Accountability variable $\mathrm{T}$ value is 1.042 with a significance level of 0.302 or greater than the probability value (p-value) of 0.05 . This means rejecting H3, it can be concluded that the Accountability variable does not significantly influence the accuracy of the giving of audit opinion.

This is caused that there are still many auditors who do not yet have an attitude of accountability and understanding of accountability in detail auditing knowledge and knowledge of the public sector, and there are still many auditors who do not understand statistics and have the ability to use computers. The results of this study support Aprianti, D (2010), Bustami, A (2013) and Fauziyah (2013) research.

\section{Discussion of Hypotheses: The effect of auditor's knowledge on the accuracy of giving audit opinions}

The variable knowledge of the calculated $\mathrm{T}$ value of -1.049 with a significance level of 0.299 or greater than the probability value (pvalue) of 0.05 . has a significance level of 0.501 . This means rejecting $\mathrm{H} 4$, it can be concluded that the Knowledge variable does not significantly influence the accuracy of the giving of audit opinion.

This is because there are still many auditors who cannot accept that there are no easy solutions, and realize that some findings can be subjective, there are still many auditors do not have auditing knowledge and knowledge of the public sector, and there are still many auditors who do not understand statistics and have computer skills. The results of this study support Aprianti, D (2010), Bustami, A (2013) and Fauziyah (2013) research.

Discussion of Hypotheses: The auditor's experience is able to moderate the influence of professionalism, objectivity, accountability, knowledge on the accuracy of giving audit opinions.

The auditor's experience variable as a moderating table, the calculated $\mathrm{T}$ value of 13.991 has a significance level of 0,000 . This means accepting $\mathrm{H} 5$, it can be concluded that the auditor's Experience variable is able to moderate the variables of professionalism, 
objectivity, accountability, knowledge of the accuracy of giving audit opinion.

Experience makes an auditor more reliable in conducting audits so as to reduce the possibility of errors during the auditing process and ultimately produce quality work and better opinion accuracy. This result is supported by the theory which experience influences the accuracy of the opinion given by the auditor.

\section{Discussion of Hypothesis : The influence of professionalism, objectivity, accountability, knowledge on the accuracy of simultaneous opinion giving}

The table from the $\mathrm{F}$ test obtained the calculated $\mathrm{F}$ value of 1.541 with a significance level of 0.204 . The probability of significance is greater than 0.05 , so professionalism, objectivity, accountability, knowledge do not influence simultaneously on the accuracy of giving audit opinion. This is because the accuracy of the giving of audit opinion is based on the SPAP that has been set and the auditor works based on the SPAP in force in Indonesia.

\section{CONCLUSION}

Based on the results of the research that has been done, the following conclusions can be drawn:

1. The variable of professionalism is 0.643 or greater than the probability value ( $\mathrm{p}$ value) of 0.05 , which means $\mathrm{H} 1$ is rejected. It can be concluded that professionalism has no effect on the accuracy of giving audit opinions.

2. Objectivity has a positive effect on the accuracy of giving an opinion audit opinion, objectivity has a significance level of 0.413 . This means rejecting $\mathrm{H} 2$.

3. The accountability variable has a significance level of 0.302 . This means rejecting $\mathrm{H} 3$, it can be concluded that the Accountability variable does not significantly influence the accuracy of the giving of audit opinion.

4. Knowledge variable has a significance level of 0.299. This means rejecting $\mathrm{H} 4$, it can be concluded that the Knowledge variable does not significantly influence the accuracy of the giving of audit.

5. The auditor experience variable as a moderating variable is a significance level of 0,000 . This means accepting H5, it can be concluded that the auditor's Experience variable is able to moderate the variables of professionalism, objectivity, accountability, knowledge of the accuracy of giving audit opinion.

6. Regression test results found that the variables of professionalism, objectivity, accountability, knowledge do not have a simultaneous effect on the accuracy of the provision of audit opinion. The probability of significance is greater than 0.05 .

\section{REFERENCES}

Aprianti, D. (2010). Pengaruh kompetensi, independensi, dan keahlian profesional terhadap kualitas audit dengan etika auditor sebagai variabel moderasi (Studi kasus pada Kantor Akuntan Publik di wilayah Jakarta Selatan).

Bustami, A. (2013). Pengaruh Independensi, Akuntabilitas Dan Profesionalisme Auditor Terhadap Kualitas Audit (Studi Empiris pada Kantor Akuntan Publik di DKI Jakarta).

Hidayat, M. T., \& RAHARDJO, R. (2011). Pengaruh Faktor-Faktor Akuntabilitas Auditor Dan Profesionalisme Auditor Terhadap Kualitas Auditor (Studi Empiris Pada Kantor Akuntan Publik Di Semarang) (Doctoral Dissertation, Universitas Diponegoro).

Nandari, A. W. S., \& Latrini, M. Y. (2015). Pengaruh Sikap Skeptis, Independensi, Penerapan Kode Etik, Dan Akuntabilitas Terhadap Kualitas Audit. E-Jurnal Akuntansi, 164-181

Sari, N. N., \& Laksito, H. (2011). Pengaruh Pengalaman Kerja, Independensi, Objektivitas, Integritas, Kompetensi Dan Etika Terhadap Kualitas Audit (Doctoral dissertation, Universitas Diponegoro). 